\title{
Septímio Severo e a Consecratio de Pertinax: Rituais de morte e poder
}

\author{
Ana Teresa Marques Gonçalves*
}

\section{RESUMO:}

Nosso objetivo neste artigo é analisar a cerimônia de deificação do Imperador Pertinax, que ocorreu após a sua morte, como definia a tradição romana, e foi promovida pelo seu sucessor, o Imperador Lúcio Septímio Severo. Esta cerimônia encontra-se descrita com riqueza de detalhes na obra de Dion Cássio, intitulada História Romana.

Palavras-chave: Consecratio, Septímio Severo, Império Romano.

Para Géza Alföldy, a crise do terceiro século teria se iniciado durante o governo do Imperador Romano Pertinax e não com os Severos. Segundo ele, no assassinato de Pertinax o poder político do exército foi demonstrado pela primeira vez, retirando do comando imperial um homem que tinha construído a imagem de bom general e amigo dos senadores ${ }^{1}$. Tal fato teria gerado a necessidade de mudanças, que foram executadas por Septímio, seu sucessor e Vingador. Apesar de o discurso continuar sendo o de retomada, de estabilização, de retorno aos bons tempos do passado, o período severiano foi marcado por reformas e novidades que não foram bem-vistas pelos estratos mais tradicionalistas do Senado. Tanto que, para Dion Cássio, passou-se após a morte de Marco Aurélio de um reino de ouro para um reino de ferro e ferrugem, ${ }^{2}$ a mesma concepção aparecendo no relato de Herodiano:

\footnotetext{
Severo chegou a Roma com todo o seu exército empunhando armas e sua aparição inspirou assombro e medo aos romanos. O povo e o Senado acudiram a recebê-lo com coroas de louros ... Saudou a todos tanto em comum como particularmente, dizendo-lhes que havia acudido como vingador do assassinato de Pertinax e que seu Império significaria o começo de uma aristocracia ... Tudo faria para imitar o Império de Marco, e de Pertinax não teria somente o nome, mas também os sentimentos. ${ }^{3}$
}

Assim, percebe-se a preocupação de Severo em criar uma imagem favorável no Senado, prometendo criar uma “aristocracia”, ou seja, um governo no qual os senadores tivessem voz e vez, e imitar duas figuras que agradavam aos senadores: Marco Aurélio e Pertinax. Pois, seguindo o pensamento de Dion Cássio, cabia a qualquer general: “representar a força das armas, antecipar os fatos pela estratégia, mas também persuadir por promessas plausíveis, conciliar com generosos presentes e seduzir com brilhantes 
esperanças”. ${ }^{4}$ E Septímio, durante seu governo, procurou se aproximar desse ideal aristocrático representado por Dion, proclamando-se Vingador de Pertinax e reformando a Guarda que o havia assassinado.

Herodiano, ao mesmo tempo que descreve as reformas empreendidas por Severo na Guarda Pretoriana e nos costumes das legiões, as critica de forma enfática:

Quando Severo recebeu a notícia da decisão do Senado e da morte de Juliano, ... criou uma forma astuta para controlar e aprisionar os assassinos de Pertinax. Enviou de forma privada mensagens secretas com generosas promessas aos tribunos militares e aos centuriões para que persuadissem aos soldados de Roma a obedecer suas ordens com disciplina. Enviou também um recado às tropas, ordenando que deixassem todas as armas no acampamento e que saíssem em paz, ... lhes ordenou que fossem prestar juramento de fidelidade a sua pessoa, plenamente confiantes de que seriam sua guarda pretoriana. Os soldados confiaram nas ordens e, persuadidos pelos tribunos, deixaram todas as armas e se apressaram a sair, vestidos somente com os uniformes de cerimônia e com coroas de louros. ... Então Severo lhes ordenou que se agrupassem para dirigir-lhes palavras de boas-vindas. Mas quando se aproximaram dele, que havia subido numa tribuna, ... com um sinal todos foram rodeados. Severo havia ordenado previamente a seus homens que, quando os pretorianos estivessem próximos a ele, com a atenção distraída, fossem cercados como inimigos. ... que os mantivessem cercados e os vigiassem com suas armas ... para que não se atrevessem a lutar por temor de serem feridos, por estarem em inferioridade numérica e desarmados frente a tropas bem armadas e numerosas. ${ }^{5}$

Severo, então, fez um longo discurso no qual demonstrou bastante clemência ao lhes poupar a vida, mas obrigou-os a se despir de todos os distintivos militares. Lembremos que, segundo Jean Béranger, a clemência era a expressão de todo o poder, pois reconhecê-la era reconhecer a autoridade da qual ela emanava. Somente homens muito poderosos podiam ser clementes. ${ }^{6}$ Os pretorianos perderam, assim, seus cargos e foram despojados de armas. Severo ainda mandou que se confiscassem as armas deixadas no Pretório e que se fechassem as portas do acampamento para que os pretorianos não conseguissem retomar suas forças. "Este foi, pois, o castigo que receberam os assassinos de Pertinax". ${ }^{7}$ Os pretorianos foram, então, banidos de Roma. ${ }^{8}$ Na História Augusta, também encontramos citação à reforma da Guarda Pretoriana, sendo um fato relevante no governo de Septímio ${ }^{9}$.

Destarte, note-se como Severo não se vingou de forma honrada, mas, segundo Herodiano, por intermédio da astúcia, um expediente considerado menor pelos aristocratas:

Este discurso encantou a maioria dos senadores, que confiaram em suas promessas. Mas alguns dos mais velhos, que conheciam o caráter de Severo, em privado já faziam a advertência de que era um homem astuto, cheio de artifícios e com uma grande capacidade de simular e dissimular qualquer coisa, mas que geralmente conseguia seu próprio proveito e conveniência. E isso, mais tarde, foi confirmado pelos fatos. ${ }^{10}$

Porém, Septímio não poderia ficar sem uma guarda pessoal. Mesmo Cômodo, que havia tido grandes problemas com a Guarda e com seus Prefeitos, não abriu mão de 
ter uma guarda pessoal, cercando-se de gladiadores. ${ }^{11}$ Então, preferiu se cercar de legionários vindos das fronteiras e não mais da Península Itálica:

Severo passou pouco tempo em Roma. Realizou uma generosa distribuição de dinheiro entre o povo e lhe ofereceu espetáculos, obsequiou esplendidamente suas tropas e selecionou os melhores para formarem as guarda imperial em lugar dos que haviam sido separados. ${ }^{12}$

Entre os melhores, estavam os homens de sua confiança vindos das tropas que ele havia chefiado. As cortes pretorianas, portanto, passaram a receber homens vindos das legiões estacionadas nas fronteiras, nas quais Severo tinha mais aliados. Até então, apenas os cidadãos nascidos na Península Itálica podiam fazer parte dos pretorianos ${ }^{13}$. Nas moedas distribuídas em Roma, começou a aparecer no anverso a legenda IMP. CAE. L. SEP. SEV. PERT. AUG., que ele usou até pelo menos 196 d.C. No reverso apareciam as imagens da Fides e da Liberalitas segurando uma cornucópia (BMC, V, n. 1-6 - aureos e denários e RIC, IV, n. 1-26 - aureos), divulgando para todos que as recebiam a sua vinculação com a figura de Pertinax. Sabemos pela História Augusta que, após a utilização oficial, anunciada no Senado, do uso do nome de Pertinax por Severo, este mandou doar sestércios e denários aos soldados ${ }^{14}$ e setecentos e vinte aureos para os embaixadores do Senado, que vieram recebê-lo quando ele entrou em Roma. ${ }^{15}$ Portanto nessas moedas distribuídas para os soldados e para os aristocratas já se divulgava a ligação de Severo com Pertinax, através de suas legendas.

Além disso, Septímio fez alterações nos costumes legionários, também muito malvistas por Herodiano em particular e pelos aristocratas em geral:

Entregou também aos soldados um soma considerável de dinheiro e lhes concedeu outros muitos privilégios que antes não tinham. Foi o primeiro, com efeito, a lhes aumentar o soldo e lhes permitiu usar anéis de ouro e a habitar com suas mulheres, o que se considerava absolutamente contrário à disciplina militar e a uma pronta disposição para a guerra. Severo foi sem dúvida o primeiro a transformar a grande fortaleza e austeridade de sua forma de vida e sua obediência perante as penalidades e o disciplinado respeito por seus chefes, ensinando-os a desejar as riquezas e conduzindo-os em direção a uma vida de moleza. ${ }^{16}$

Vê-se como Herodiano interpreta as medidas tomadas por Severo, e que contradizem a tradição, como prenúncios de desgraças para o Império, pois mudanças não eram bem-vistas pelos aristocratas, principalmente quando estas mudanças faziam desviar o dinheiro do erário dos gastos com adlectiones para aumentar o soldo do exército, além de fortalecer os legionários e pretorianos politicamente no processo de ascensão e deposição dos Príncipes.

A informação de Herodiano de que Severo foi o primeiro a aumentar-lhes o soldo é equivocada, pois desde Domiciano os legionários vinham recebendo aumentos 
nos salários. A partir do governo de Septímio, os centuriões podiam usar o anulus aureus, signo da ordem eqüestre, pois ficou estabelecido que eles seriam aceitos nesta ordem, o que lhes abria uma ampla carreira militar e civil. ${ }^{17}$ Antes de Severo, os soldados só podiam se casar após se licenciarem, mas muitos viviam com suas esposas de forma ilegal. Severo apenas legalizou a situação e permitiu que as famílias acompanhassem os legionários e se fixassem em cidades próximas aos acampamentos. Assim, a importância dada à disciplina militar não se revestia apenas de um caráter prático, devido às constantes intromissões de homens em armas na ascensão e deposição dos soberanos. A noção de disciplina é muito antiga e cara aos romanos; era um modo de vida que se mesclava à própria constituição do Estado. A disciplina do soldado, deste modo, envolveria uma obediência absoluta, simplicidade de comportamento, sacrifício e força para enfrentar todos os sacrifícios pela pátria, misturando-se com a noção de patientia. ${ }^{18}$ Observando-se esta noção tradicional, percebe-se como as reformas trazidas por Septímio podiam realmente desagradar setores sociais mais tradicionais.

Por isso, Géza Alföldy defende que foram essas mudanças, entre outras promovidas pelos Severos, que convenceram os contemporâneos de que uma transformação geral estava em processo, criando a noção de que se estava numa crise capaz de destruir o Império, pois todas as mudanças eram atacadas por aqueles que defendiam a ordem tradicional e a vigência dos costumes ancestrais. Defendia-se que todas as mudanças advinham no fundo do declínio moral, que devia ser combatido. Devido a isso, todos os Imperadores que queriam contar com um mínimo de apoio senatorial se diziam reconstrutores da ordem, restauradores do passado. Assim, reformadores como Septímio sempre enfatizaram que suas medidas eram de restauração e não de renovação. ${ }^{19} \mathrm{E}$ a utilização do título tradicional de Vingador e a produção de uma cerimônia, também já tradicional, de apoteose do Príncipe morto ajudavam a enfatizar esta retomada da ordem e da normalidade no seio do Império. Por isso, Septímio solicitou ao Senado que se realizasse durante seu governo a cerimônia de transformação de um homem poderoso, Pertinax, Imperador assassinado pela Guarda Pretoriana, em Deus, chamada consecratio ou apoteose. Como afirma Vernant: “A morte não é uma simples privação da vida, um óbito: é uma transformação de que o cadáver é ao mesmo tempo instrumento e objeto, uma espécie de transmutação do indivíduo que se opera no e pelo corpo". ${ }^{20}$

Diante de medidas que desagradavam tanto aos senadores, Septímio buscou aproximar-se ainda mais da figura de seu antecessor Pertinax, muito bem-visto pela elite 
romana, por ter tido um governo breve, mas no qual procurou se aproximar dos senadores. Como o Senado já havia lhe dado honras divinas, Septímio apressou-se em garantir sua consecratio, cerimônia esta que foi descrita por Dion Cássio, com um bom número de detalhes, e que passaremos a analisar neste artigo:

... Ele (Septímio Severo) mandou erguer um templo para Pertinax e decidiu que seu nome seria mencionado por todos os sacerdotes e em todos os juramentos. Ele também ordenou que uma estátua de ouro de Pertinax fosse carregada até o Circus num carro puxado por elefantes e que três tronos dourados fossem erigidos nos outros anfiteatros em sua honra. Seu funeral, apesar do tempo transcorrido desde a sua morte, foi feito de acordo com os costumes. No Fórum romano foi construída uma plataforma de madeira enfeitada com mármore e sobre ela foi posto um templo sem paredes, mas cercado de colunas feitas com habilidoso trabalho de marfim e ouro. Neste lugar também foi posto um carro fúnebre feito com os mesmos materiais, cercado por bustos de ambos os lados e por imagens de animais marinhos, e adornado com cortinas de púrpura e ouro. Então, sobre a plataforma foi posta a efígie de Pertinax feita de cera, vestida com seu traje triunfal ..., parecendo realmente uma pessoa dormindo. Enquanto o corpo estava deitado nesta posição de magnificência, Severo e os senadores e suas esposas se aproximaram vestindo trajes matutinos. As mulheres se sentaram sob um pórtico, enquanto nós, homens, nos sentamos sob o céu aberto. Enquanto passavam na frente da plataforma imagens de todos os romanos famosos do passado, coros formados por jovens e homens cantavam um hino fúnebre para Pertinax. Seguiu-se a isso, uma procissão representando todas as regiões conquistadas, representadas por figuras de bronze vestidas com roupas nativas, e representantes de todas as associações da cidade (litores, escribas, arautos e todo o resto). Então, desfilaram imagens de outros homens que se distinguiram por suas explorações, invenções ou maneira de viver. Após eles, vieram a cavalaria e a infantaria armadas, os cavalos de raça, e todas as ofertas funerárias que o Imperador e nós, senadores, e nossas esposas, e os mais distintos cavaleiros, e comunidades, e as associações da cidade enviaram. ... Enquanto tudo isso passava, Severo subiu na rostra e leu um elogio para Pertinax. Nós gritamos nossa aprovação em diversos momentos ao longo do discurso, ora louvando ora lamentando Pertinax, mas nossos gritos foram ainda mais fortes quando ele concluiu. Finalmente, quando o carro fúnebre se pôs em movimento, nós lamentamos e choramos juntos. $\mathrm{O}$ ataúde foi carregado da plataforma até o carro fúnebre pelos altos sacerdotes e magistrados, não apenas os que estavam ocupando as funções públicas, mas também os eleitos para o ano seguinte. Eles entregaram o ataúde para ser carregado pelos cavaleiros. Todos nós, agora, marchávamos à frente do carro fúnebre, alguns batendo no peito, outros tocando flauta, e o Imperador seguia atrás de todos. E nesta ordem, chegamos no Campo de Marte. Lá uma pira tinha sido construída em forma de torre, tendo três pavimentos e adornada com marfim e ouro, bem como por um bom número de estátuas, enquanto no topo foi posta uma carruagem, que o próprio Pertinax tinha dirigido. Dentro da pira, foram jogadas as ofertas funerárias e o ataúde foi posto no topo. Então Severo e os parentes de Pertinax beijaram a efígie. O Imperador subiu numa tribuna, enquanto nós, o Senado, excetuando-se os magistrados, tomamos lugar numa plataforma de madeira para ver a cerimônia de forma segura e conveniente. Os magistrados e os membros da ordem eqüestre, vestidos de maneira conveniente, e da mesma forma a cavalaria e a infantaria fizeram uma procissão em torno da pira, fazendo intrincadas evoluções, tanto em situações de paz quanto de guerra. Então, o último dos cônsules aplicou fogo na estrutura, e enquanto o fogo ardia, uma águia foi solta. Desta forma, Pertinax tornou-se imortal". ${ }^{21}$

A partir da realização dessa cerimônia, Septímio se tornou o Vingador não mais de um homem mortal, mas de um divus, fazendo crescer sua imagem pública e seus atributos. Tanto que, junto com os parentes de Pertinax, ele também beijou a efígie de cera do morto. Esta ligação com os divi sempre foi uma imagem cara aos romanos, já que, alguns anos após esta consecratio, Caracala e Geta, filhos e herdeiros de Septímio, fariam em conjunto a apoteose do pai. 
A ocorrência da apoteose de Pertinax é citada em todas as fontes textuais que se referem ao período severiano. Aurélio Victor a cita com grande ênfase. ${ }^{22}$ Na Epitome de Caesaribus,conhecemos um pouco do que se dizia sobre o governo de Pertinax: “Sob o Império de Pertinax nós vivemos em segurança; nós não tememos ninguém. Glória ao pai mais piedoso, ao pai do Senado, ao pai de todos os bons cidadãos”. ${ }^{23}$ A cerimônia também é citada como um tipo de Funus Censorium na História Augusta, ${ }^{24}$ isto é, uma cerimônia feita com total apoio do Senado e às expensas dele. ${ }^{25}$

Pouco se sabe sobre o que ocorreu com as cinzas de Pertinax. É interessante notar que Septímio não as colocou no Mausoléu dos Antoninos, pois, ao contrário do que ele faria algum tempo depois desta cerimônia, se atrelando à dinastia Antonina, Pertinax em vida jamais havia se declarado um continuador dos Antoninos, talvez por estar ainda muito próximo das lembranças dos atos de Cômodo. Deste modo, pela História Augusta, existe a informação jamais comprovada de que suas cinzas foram levadas para a sepultura do avô de sua esposa. ${ }^{26}$

De acordo com Arnaldo Momigliano, havia uma sacralidade inerente ao poder soberano, que necessitava de legitimação devido a seus poderes excepcionais. E o culto póstumo era o mais fácil para os romanos, pois tinham já um modelo reconhecido na apoteose de Rômulo e era facilmente aceito em todas as partes do Império como signo de estabilidade e continuidade do Império. ${ }^{27}$ Ao promover a apoteose de Pertinax, Septímio mais uma vez buscava indicar uma continuidade com o passado, uma busca de restauração.

Como nos recorda Elias Bickerman, não devemos confundir divindade e associação com o divino. O monarca pela graça dos deuses, por definição, não era uma divindade por si mesmo. ${ }^{28}$ Desta forma, não era o soberano que, por vontade própria ou qualquer direito da função de Imperador, passava a fazer parte do panteão enquanto divus, mas os deuses que o recebiam entre eles, a partir de uma solicitação do Senado. A autorização imperial era necessária para que uma cidade ou uma província estabelecesse culto a um Imperador vivo ou morto ou a um membro da casa imperial, não se constituindo, portanto, num ato espontâneo de admiração pelo soberano ou pelos que o cercavam, mas num ato institucional e político. E não existia uma forma de culto universal, válida para toda a extensão do Império, mas, ao contrário, cada cidade, cada província fazia o culto de acordo com seus rituais mais tradicionais. Tanto que, em muitas cidades do Oriente, os Imperadores vivos ou mortos eram cultuados com o epíteto de theos, pois a divinização de uma pessoa em vida não era estranha às suas 
tradições. Theos no Oriente era um termo comum aplicado aos reis helenísticos e aos Imperadores Romanos. Essa terminologia não foi aplicada nas províncias ocidentais, pois sua posição oficial era clara: o Imperador não era aceito como deus em vida, pois somente após a morte e a realização dos ritos descritos acima ele podia ser feito divus. ${ }^{29}$

Existia um procedimento padrão e critérios claros para a criação de um divus no Ocidente. Depois do funeral do Imperador, o Senado se reunia e discutia o estabelecimento de um culto oficial em sua memória, ou a sua damnatio memoriae. E o ritual era como o descrito acima, cheio de meandros políticos muito bem estabelecidos. S. Weinstock ressalta que a consecratio era antes de tudo um ato religioso, no qual alguém era feito sacrum, uma propriedade das divindades, por decisão do Senado. ${ }^{30}$ Todavia, acreditamos que na Roma antiga a religião era inseparável da política, o que nos leva também a revestir o ato da consecratio dos Imperadores de um manto político.

Simon Price compara essa atribuição do Senado ao papel do Vaticano na canonização dos santos. Segundo ele, ambos são árbitros supremos em termos religiosos. A criação de um divus como a de um santo era o reconhecimento de um estado de coisas e precisava de testemunhas. Na passagem do segundo para o terceiro século d.C., todos os presentes à cerimônia da apoteose tinham a chance de ver a águia levando a alma do morto para os céus. ${ }^{31}$ Na época de Augusto, tornou-se necessário que Numerius Atticus afirmasse ter visto a alma de Otávio indo para os céus. ${ }^{32}$ Já no relato da apoteose de Pertinax não aparece tal testemunha.

Septímio Severo instigou o Senado a conceder a consecratio a Pertinax. Pelo texto de Dion Cássio, vemos que, antes mesmo da efetivação da cerimônia, Septímio já havia mandado erguer um templo para Pertinax, e mandou fazer uma estátua de ouro para ser posta no Circus e tronos dourados para serem colocados nos anfiteatros, como se Pertinax passasse a ter lugar cativo nos lugares onde se realizavam espetáculos, o que não estava de acordo com a tradição, pois ele deveria ter esperado primeiro a cerimônia ter sido efetivada para depois fornecer honras para o morto. Esta estátua de ouro feita para Pertinax nos lembra uma outra mandada erigir por Cômodo, para honrar a memória de Marco Aurélio após sua morte, e posta na porta do Senado. ${ }^{33}$ Portanto, era uma prática tradicional mandar erigir estátuas de ouro para Imperadores divinizados e dar ordens para colocá-las em locais públicos, como a porta do Senado e o interior do Circo, pois elas não apenas honravam a memória dos divinizados como também daqueles que tinham mandado erigi-las. 
Segundo Elias Bickerman, de acordo com a tradição, a consecratio era apenas uma cerimônia na qual se garantia a suprema honra a um grande homem, mas o mais importante ainda estaria por vir. Após a apoteose é que se deveria organizar e introduzir um novo culto, isto é, o divus se transformava num novus numem, podendo receber templos, sacerdotes, estátuas de culto. Assim, para Bickerman, o voto do Senado era declarativo e não constitutivo, ${ }^{34}$ isto é, os senadores declaravam que o morto podia ser divinizado, mas o culto era decidido na relação travada entre o novo Imperador e as províncias. E ele identifica a origem deste culto no mito de Hércules, no qual o herói escapou da morte ascendendo aos céus, após seu corpo ser queimado. ${ }^{35}$

Como demonstra G. W. Bowersock, os habitantes do Império Ocidental, de Augusto a Constantino, não faziam pedidos para governantes mortos e não esperavam milagres deles, apesar de os venerarem, sabendo distinguir um divus de um deus. ${ }^{36}$ Mas isso não diminuía a posição religiosa e política dos divi. Principalmente porque a organização do culto imperial nas províncias estava nas mãos dos chefes políticos e sociais das comunidades, que tinham dinheiro e interesse em oferecer templos e estátuas para os divi, na tentativa de mostrar sua lealdade ao Império e ao sucessor do morto no comando, demonstrando sua adesão ao regime. O culto, portanto, tem a ver com lealdade e tradição para os romanos, e não com fé ou crença em última instância. ${ }^{37}$ No Oriente havia se desenvolvido um culto mais helenístico no qual se admitia a divinização do Imperador em vida, sacrifícios feitos diante de estátuas imperiais, ${ }^{38}$ oferendas votivas em honra dos soberanos ${ }^{39}$ e até mesmo o desenvolvimento de cultos mistéricos envolvendo os soberanos vivos ou mortos. ${ }^{40}$

Era necessário divulgar os atos imperiais, nem sempre tradicionais, realizados por Septímio. Há, por exemplo, um medalhão, datado de 193 d.C. e guardado no Museu Cívico de Bolonha, estudado por Francesco Gnecchi, que mostra no anverso a legenda Divus Pertinax Pius Pater em volta de um busto, muito parecido com o busto de Pertinax que pertence ao acervo do Museu Capitolino. No reverso do medalhão, há a legenda Aeternitas inscrita sobre a imagem de uma estátua sendo conduzida numa carruagem puxada por quatro elefantes, ${ }^{41}$ relembrando a condução da estátua de ouro de Pertinax até o Circo, narrada por Dion Cássio.

Foi construída uma plataforma especial, cercada de colunas de marfim e ouro para servir de palco para a exposição da efígie de Pertinax durante sua apoteose, como se fosse a construção de um palco, no grande teatro político de Roma, no centro do Fórum, espaço urbano político-religioso por excelência da Cidade-Estado. Na Rostra (o 
palanque dos oradores), Septímio, por intermédio da laudatio funebris ou rogus feita à memória do morto, teria a chance de mais uma vez ressaltar sua vinculação com Pertinax, sua posição de Vingador de um divus. Nessa rostra, Septímio poderia demonstrar toda sua retórica e sua eloqüência, como Marco Antônio, no passado republicano, havia se vinculado à memória de Júlio César. S. Weinstock, em sua obra Divus Iulius, analisa a importância deste discurso de Marco Antônio para a construção da divindade de César e para a reversão do momento político, conseguindo convencer a população da importância de se perseguir os assassinos de César (Brutus e Cassius), ${ }^{42}$ demonstrando como o momento desse discurso na rostra é fundamental no ritual da consecratio. A apoteose de César serviu de base para os funerais e a consecratio de Augusto.

Construiu-se também um carro fúnebre especial para levar a efígie de cera de Pertinax até a pira no Campo de Marte. Não se tratava de um carro comum, mas de um veículo em cujas laterais apareciam os bustos de romanos ilustres, aos quais se vinculava o próprio Pertinax e o seu Vingador. Enquanto o Imperador e os senadores e suas esposas lhe prestavam as últimas homenagens, desfilaram na frente do carro estátuas de romanos famosos, vinculando passado, presente e futuro. A efígie de Pertinax foi vestida com um traje especial: as roupas usadas por um general triunfador, pois ele estava pronto para triunfar sobre a morte e para ter sua memória guardada para sempre. S. Weinstock demonstrou que ter a honra de envergar tal vestimenta, não apenas durante a cerimônia do triunfo, indicava que o homem que a usava era visto como um legítimo detentor do poder, e que atravessar a cidade numa carruagem feita especialmente para si, estando vivo ou morto, também indicava a posse de um poder soberano. ${ }^{43}$ Assim, a construção de um carro fúnebre tão imponente não era apenas um ato de magnificência, mas um ato político, no qual a reafirmação do poder legítimo de Pertinax auxiliava a reafirmar o poder político de seu Vingador, Septímio. Severo inclusive se colocou como membro da família de Pertinax ao beijar a efígie junto aos parentes do morto, quase ao final da cerimônia.

Para Jean-Claude Richard, os funerais imperiais apresentavam vários aspectos militares. Ele é um dos defensores da concepção de que as ideologias do triunfo e da apoteose imperial tinham pontos comuns, pois os funerais dos Príncipes evocavam certos aspectos das pompae triumphales. Essa cerimônia indicaria honras militares, de origem muito antiga, rendidas aos Imperadores enquanto chefes das legiões. Desse modo, ele entendeu e procurou explicar a presença da cavalaria e da infantaria na 
cerimônia de apoteose. Lembremo-nos de que, após o desfile das estátuas de homens do passado, se seguiu uma procissão de figuras de bronze, representando as regiões conquistadas, e as chamadas decursio, evoluções dos legionários que relembravam ritos antigos feitos em torno de chefes mortos em combate. ${ }^{44}$ Antes de se atear fogo à pira, mais uma vez, os militares fizeram evoluções, lembrando treinamentos feitos tanto em situação de paz quanto de guerra. Para Richard, essa presença do exército sublinharia uma característica guerreira tomada de empréstimo do funus militare, que com o tempo havia se integrado no ritual imperial. A decursio, um simulacro de batalha, permanecia uma última homenagem rendida ao chefe das legiões e a sua felicitas no teatro de suas vitórias, relembrando que o Príncipe era antes de tudo um Imperator, o comandante de todas as legiões. ${ }^{45}$ Segundo Cecilia Ames, Imperator primeiramente indicava o possuidor do Imperium no campo de batalha, mais tarde o título podia ser outorgado ao general por aclamação dos soldados depois da batalha e posteriormente deveria ser reconhecido pelo Senado, e a partir disso é que se convertia num título de honra. ${ }^{46}$

Na concepção de Richard, o triunfo já era uma pré-divinização imperial, pois, mais que uma comemoração, já se constituía numa promessa de apoteose. No triunfo, a um general vitorioso era permitido escapar da condição humana e partilhar provisoriamente a condição dos deuses. Na apoteose, ao morto era dada a possibilidade de compartilhar a imortalidade divina por intermédio da manutenção de sua memória. Por isso era tão importante que o nome de Pertinax fosse repetido nas orações e nos juramentos, para que não fosse esquecido, como nos lembra Dion Cássio. Por isso também era importante se guardar o luctus publicus, uma semana de luto em memória do morto. ${ }^{47}$ Interessante notar que nem Pertinax nem Septímio realizaram cerimônias de triunfo, mas receberam de seus herdeiros no poder a indicação da apoteose, em cuja cerimônia ganharam também, de certa forma, honras triunfais. Já para Jean Bayet, os sacerdotes romanos e sua atuação junto aos magistrados foram os responsáveis pela prédivinização dos Imperadores. Para ele, era a detenção do cargo de Pontifex Maximus que garantia aos soberanos tantas possibilidades de divinização antes e depois da morte. 48

Porém, não eram apenas os elementos militares que tinham grande importância na cerimônia. Seguimos, assim, a concepção de Jean Beaujeu, que defende que todos os aspectos ligados ao culto dos soberanos, vivos ou mortos, se revestem sempre de uma dupla significação, tanto religiosa quanto política. ${ }^{49}$ Todos os elementos políticos do Império se encontravam representados, numa ordem crescente de poder: representações 
das províncias conquistadas, representantes das associações de Roma, eqüestres e senadores. Esta era a posição de cada um diante da efígie de Pertinax e de cada segmento social na procissão que levava a efígie do Fórum ao Campo de Marte. Na narrativa de Dion Cássio fica clara a participação da plebe romana: ela apenas assiste à cerimônia, sem nenhum poder de intervenção política mais efetivo. E após todos, fechando o cortejo, aparecia o Imperador Septímio.

Portanto, apesar de todos os elementos militares, a cerimônia da apoteose era também um importante momento político, no qual cada grupo deveria saber o seu lugar e respeitar o dos outros. E enquanto o fogo ardia, lançava-se uma águia, cuja função era levar a alma do morto para junto das divindades. Pela presença dessa águia no cerimonial, autores como Anne Roes defendem que a cerimônia da apoteose imperial tem uma origem puramente oriental. Segundo ela, a águia era um símbolo solar, por ser um animal que voa alto e que aparece representado em túmulos asiáticos, gregos e sírios. ${ }^{50}$

Devemos também lembrar mais duas características dessa cerimônia.Tratava-se de um funus imaginarium, pois todo o ritual foi feito em torno de uma efígie de cera, uma vez que o corpo de Pertinax já havia sido incinerado (durante as exequiae, isto é, as cerimônias particulares e familiares), como também ocorreria mais tarde na apoteose de Septímio; e foi um funus publicum, isto é, uma cerimônia de caráter público, feita à custa do tesouro público e cuja realização deveria ser conhecida por todos os habitantes do Império.

Segundo Bickerman, era fundamental para os romanos esta diferenciação entre funeral privado, da família (sacra privata), e funeral público (sacra publica), o que gerou a criação de um duplo funeral: no primeiro, o corpo era incinerado ou inumado de acordo com a tradição familiar, e, no segundo, a figura de cera era cremada, sem deixar resíduos sobre a terra, pois, para ser comparado a Hércules e Rômulo, o corpo do Imperador deveria desaparecer por completo. Como lembra Bickerman, foi exatamente pelo fato de os companheiros de Hércules não terem achado vestígios de cinzas na pira onde seu corpo foi queimado no monte Oeta, após ele receber o oráculo de Delfos, como reconta Diodoro Sículo (IV, 38.3-5), que se considerou que ele virou deus. ${ }^{51}$ Também se deve ter em conta que não havia a obrigatoriedade da incineração na sacra privata. Se a família tradicionalmente enterrava os mortos, isso podia ser feito na cerimônia privada, pois apenas na cerimônia pública se tinha a obrigatoriedade da cremação. ${ }^{52}$ 
Em outro texto, Richard analisa as origens políticas da apoteose dos Imperadores, percebendo-as nos fatos ocorridos com Enéas, Rômulo e César. ${ }^{53}$ Estes seriam os cânones da consecratio de Otávio Augusto, que teria servido de modelo, com algumas adaptações, para os sucessores. Normalmente, a primeira imagem que aparece nos funerais imperiais era aquela de Enéas, o herói fundador, que vinculava a História de Roma à guerra de Tróia. Com Rômulo veio a noção de que o corpo deveria desaparecer, como na sua transformação no deus Quirino, de onde advinha a necessidade da cremação. E com César teria vindo a importância do discurso político antes da cremação.

Simon Price busca a origem da cerimônia da apoteose nos modelos seguidos pelos funerais dos aristocratas romanos. ${ }^{54}$ Os funerais aristocráticos, por exemplo, também seguiam o caminho que ia do Fórum até o Campo de Marte, onde era feita a cremação, como na narrativa de Dion Cássio. Como nos lembra Simon Price, o Campo de Marte era um local privilegiado para as cremações. Tecnicamente ele estava fora do pomerium e era um local de grande importância cívica, visto que muitas eleições de magistrados foram feitas lá. ${ }^{55}$ Interessante notar como o soberano, no caso Septímio, chamou para si a função de fazer a laudação do morto, antes feita por um membro da família do morto. Como Vingador de Pertinax, Severo se sentia como seu filho, pois os filhos eram tradicionalmente os principais vingadores das injustiças sofridas pelos pais. Além do mais, a virtude era o critério para aplicar a deificação, e o virtuoso era o que trabalhava pela comunidade, como Hércules havia feito, e, ao promover a cerimônia de apoteose de Pertinax, Septímio ratificou sua posição de Vingador de um homem virtuoso, como numa espécie de transmissão de autoridade pelo rito de passagem de Pertinax de humano a divus.

David Cannadine, na introdução do livro Rituals of Royalty, comenta que não se pode separar o estudo da política da análise das cerimônias, pois há o poder do cerimonial e as cerimônias do poder. Para se exercer a soberania tem-se que misturar elementos políticos e fenômenos místicos. O espetáculo no teatro do poder não é um elemento subsidiário, mas parte efetiva do poder político, pois por intermédio de sua realização se busca a confirmação do consenso e da manutenção da hierarquia nas comunidades e a legitimidade do soberano. As cerimônias auxiliam, assim, o soberano a tornar o seu poder visível, mesmo para aqueles que não o detêm. Política e cerimonial não podem ser separados, já que o ritual não é uma máscara para o poder, mas é ele próprio um tipo de poder. ${ }^{56}$ As cerimônias são meios para se manter a ordem social. $\mathrm{O}$ 
cerimonial aparece, sobretudo, em momentos nos quais um indivíduo passa de um papel a outro, podendo ser encarado como um fenômeno teatral e uma forma de comunicação, pois confere prestígio a quem participa dele, legitima papéis e confirma o consenso. Por isso, é fundamental ao poder político deter o controle das cerimônias. ${ }^{57}$

Outra pesquisadora que tem enfatizado a importância das cerimônias em Roma, para o fortalecimento da identidade e do consenso, é Florence Dupont. Em sua obra L'Acteur-Roi ou le Thêatre dans la Rome Antique, ela enfatiza que a autoridade é conquistada à custa de uma liderança carismática que precisa desenvolver um componente visual. Para ela, uma das mais importantes cerimônias da "política do espetáculo romana” foi exatamente a apoteose dos soberanos mortos feita pelos seus sucessores. Nela cada setor social tinha a possibilidade de se estruturar hierarquicamente. O olhar do cidadão era necessário para que se instaurasse a clivagem entre governantes e governados, entre magistrados e plebeus, entre senadores e cavaleiros. Por isso, eles possuíam lugares tão demarcados. E durante a cerimônia, o Imperador se fazia visível como Imperador, fechando a procissão fúnebre. Era também primordial a integração dos provinciais por intermédio da representação das regiões conquistadas e das oferendas dadas e lançadas na pira, para serem queimadas junto com a efígie de cera. A elite provincial dependia da legitimidade do Imperador para também se legitimar como elite. Por isso, sua presença na cerimônia era fundamental. ${ }^{58}$ Sendo assim, a ligação entre vivos e mortos se exprimia claramente nos rituais fúnebres. ${ }^{59}$

Na busca desse consenso era necessário divulgar a ocorrência dessa cerimônia para além da cidade de Roma. E para divulgar tão importante cerimônia, Septímio mandou cunhar moedas com este tema. As que nos restam foram cunhadas em Roma. Em todos os anversos, cunhou-se o busto de Pertinax acompanhado da legenda DIVUS. PERT. PIUS. PATER. Nos reversos, encontram-se os símbolos funerários mais tradicionais, como a águia sobre o globo terrestre (BMC, V, n. 479 e 480.1 - denários; RIC, IV, n. 24 A e 24 B - denários e RIC, IV, n. 660 A e B - sestércios) e a representação da pira funerária (BMC, V, n. 480.2 - denário e RIC, IV, n. 660 C sestércio), com a legenda CONSECRATIO S(enatus) C(onsultum).

Para Janine Balty, Septímio mandou as casas da moeda de Roma cunharem no anverso um busto de Pertinax muito parecido com as estátuas de Severo, que eram produzidas nos ateliês oficiais romanos da época. Segundo a pesquisadora, Severo buscou, desta forma, assimilar sua imagem à de Pertinax, passando a idéia de que ele 
era o seu continuador, integrando os traços do Imperador defunto divinizado ao rosto do próprio Septímio. ${ }^{60}$

Como demonstra C. J. Simpson, fazer a apoteose de alguém era demonstrar uma apropriada piedade em relação ao morto. ${ }^{61}$ Sendo assim, a realização dessa cerimônia e a sua posterior divulgação auxiliavam também o Imperador a fortalecer a sua imagem de Piedoso. Além disso, a divinização dos Imperadores mortos se unia ao culto imperial, um importante fator de coesão política dentro do Estado romano. Mediante a dedicação de estátuas e as devoções, que eram muito mais prestações de homenagem do que adoração nas províncias ocidentais, as cidades e os súditos dos Imperadores demonstravam sua lealdade e seu comprometimento com a manutenção da ordem política vigente. ${ }^{62}$ A divinização imperial era, assim, um símbolo de unidade e identidade que englobava culturalmente todos os habitantes do mundo romano. ${ }^{63} \mathrm{O}$ poder político e a legitimidade não se apoiavam somente em impostos e exércitos, mas também em concepções e crenças humanas. Deste modo, era necessária uma mistificação que alçasse o Imperador sobre os demais seres humanos.

Os súditos não aderem necessariamente a um soberano em particular, mas a um soberano idealizado, que simbolizava a ordem do mundo. Todos os momentos nos quais era possível se realizar uma fusão entre o Imperador e as divindades eram aproveitados, porque possibilitavam a coalizão da ordem moral com a ordem política. ${ }^{64}$

Portanto, não foi à toa que tanto o governo de Sepímio quanto o de seus filhos Geta e Caracala começaram com a realização de cerimônias de apoteose, já buscando neste ritual uma legitimação para o governo que se iniciava, com Severo promovendo a apoteose de Pertinax e recebendo a mesma honra no governo de seus filhos e herdeiros. Tratava-se de um mecanismo político importante para aumentar ainda mais a legitimidade do governo e a autoridade do governante, após a ocorrência de guerras civis.

GONÇALVES, Ana Teresa Marques. Septimius Severus and the Pertinaces' Consecratio: Death and power rithuals. História, São Paulo, v. 26, n. 1, p 20-35, 2007.

Abstract: Our aim is analyze the Emperor Pertinaces' deification cerimony, which occurred after his death, as defined by the Roman tradition, promoted by his successor, the Emperor Lucius Septimius Severus. That ceremony is described in detail in Dio Cassius' work, Roman History.

Keywords: Consecratio, Septimius Severus, Roman Empire 
Artigo recebido em 04/2007. Aprovado em 06/2007.

\section{NOTAS}

* Professora de História Antiga e Medieval - Faculdade de Ciências Humanas e Filosofia - UFG - 74001970 - Goiânia/GO. E-mail: anteresa@terra.com.br

${ }^{1}$ ALFÖLDY, G. The Crisis of the Third Century as Seen by Contemporaries. Greek, Roman and Byzantine Studies, Durham, v.15, p.104, 1974.

${ }^{2}$ CASSIO DIONE. Storia Romana. Traduzione di Alessandro Stroppa. Milano: BUR, 1998. LXXII, 36.4 .

${ }^{3}$ ERODIANO. Storia dell'Impero Romano dopo Marco Aurelio. Testo e versione di Filippo Càssola. Firenze: Sansoni, 1967, II, 14.1-3.

${ }^{4}$ CASSIO DIONE. Op. cit., LXXI, 3.1.

${ }^{5}$ ERODIANO. Op. cit., II, 13.1-5.

${ }^{6}$ BÉRANGER, J. L'Idéologie Impériale dans l'Histoire Auguste. In: Bonner Historia Augusta Colloquium. Bonn: Rudolf Habelt Verlag, 1976. p.52.

${ }^{7}$ ERODIANO. Op. cit., II, 13.12.

${ }^{8}$ CASSIO DIONE. Op. cit., LXXV, 1.1.

${ }^{9}$ The Scriptores Historiae Augustae. English translation by David Magie. London: William Heinemann, 1953. v.1 e 2 (The Loeb Classical Library), Vida de Severo, VI e XVII.

${ }^{10}$ ERODIANO. Op. cit., II, 14.4.

${ }^{11}$ CASSIO DIONE. Op. cit., LXXIII, 17.1.

${ }^{12}$ ERODIANO. Op. cit., II, 14.5.

${ }_{13}^{13}$ PASSERINI, A. Le Coorti Pretorie. Roma: Angelo Signorelli, 1939. p.174-180.

${ }^{14}$ The Scriptores Historiae Augustae, op. cit.,Vida de Severo, V.

${ }^{15}$ Idem, VI.

${ }^{16}$ ERODIANO. Op. cit., III, 8.4-5.

${ }^{17}$ PASSERINI, A. Op. cit., p.175-176.

${ }^{18}$ LIND, L. R. The Idea of the Republic and the Foundations of Roman Political Liberty. In: Studies in Latin Literature and Roman History. Bruxelles: Latomus, 1986. t.4, p.61-67.

${ }^{19}$ ALFÖLDY, G. Op. cit., p.103-110.

${ }^{20}$ VERNANT, J.-P. Figuras, Ídolos, Máscaras. Lisboa: Teorema, 1991. p.23.

${ }^{21}$ CASSIO DIONE. Op. cit., LXXV, 4.2-6 e 5.1-6.

${ }^{22}$ SEXTUS AURELIUS VICTOR. Histoire des Césars. Traduit par Pierre Dufraigne. Paris: Les Belles Lettres, 1975, XX.

${ }^{23}$ Epitome de Caesaribus. Traduction de M.N.A. Dubois. Paris: C.L.F. Panckoucke, 1846, XVIII.

${ }^{24}$ The Scriptores Historiae Augustae. Op. cit.,Vida de Pertinax, XV.

${ }^{25}$ Idem,Vida de Severo, VII.

${ }^{26}$ Idem, Vida de Pertinax, XIV.8.

${ }^{27}$ MOMIGLIANO, A. De Paganos, Judíos y Cristianos. México: FCE, 1992. p.161-169.

${ }^{28}$ BICKERMAN, E. Consecratio. In: Le Culte des Souverains dans l'Empire Romain. Genève: Fondation Hardt, 1973. t.19, p.7.

${ }^{29}$ PRICE, S. R. F. Gods and Emperors: The Greek Language of the Roman Imperial Cult. Journal of Hellenic Studies, London, v.104, 1984, p. 79-83.

${ }^{30}$ WEINSTOCK, S. Divus Julius. Oxford: Clarendon Press, 1971. p.386.

${ }^{31}$ PRICE, S. R. F. Gods and Emperors: The Greek Language of the Roman Imperial Cult. Journal of Hellenic Studies, London, v.104, 1984, p.83-84.

${ }^{32}$ CASSIO DIONE. Op. cit., LVI, 46.2.

${ }^{33}$ Idem, LXXII, 34.1. 
${ }^{34}$ BICKERMAN, E. Op. cit., p.13.

${ }^{35}$ Idem, p.14.

${ }^{36}$ BOWERSOCK, G. W. Greek Intellectuals and the Imperial Cult in the Second Century A. D. In: Le Culte des Souverains dans l’Empire Romain. Genève: Fondation Hardt, 1973. t.19, p.180.

${ }^{37}$ Idem, p. 184.

${ }^{38}$ PRICE, S. R. F. Between Man and God. Journal of Roman Studies, London, v.70, 1980, p.28-43.

${ }^{39}$ FISHWICK, D. Votive Offerings to the Emperor? Zeitschrift fur Papyrologie und Epigraphik, Bonn, v.80, 1990, p.121-130.

${ }^{40}$ PLEKET, H. W. An Aspect of the Emperor Cult: Imperial Mysteries. Harvard Theological Review, Cambridge, v.58, n.4, 1965, p.331-347.

${ }^{41}$ GNECCHI, F. Nuovo Medaglione di Pertinace. Rivista Italiana di Numismática, Milano, v.18, 1905, p.476-480.

${ }_{42}$ WEINSTOCK, S. Op. cit., p.367-370.

${ }^{43}$ Idem, p.61-68.

${ }^{44}$ RICHARD, J.-C. Les Aspects Militaires des Funérailles Impériales. Mélanges de l'École Française de Rome, Paris, v.78, 1966, p.314.

${ }^{45}$ Idem, p.315-320.

${ }^{46}$ AMES, C. El Título Imperial Romano y la Problemática del Principado. Estudios Clásicos, Madrid, v.41, 1999, p.55.

${ }^{47}$ RICHARD, J.-C. Recherches sur Certains Aspects du Culte Impérial. Aufstieg Niedergang und Romischen Welt, Berlin, v.2, n.16, parte 2, 1978, p.1125-1127.

${ }^{48}$ BAYET, J. Croyances et Rites dans la Rome Antique. Paris: Payot, 1971. p.275-352.

${ }^{49}$ BEAUJEU, J. Les Apologètes et le Culte du Souverain. In: Le Culte des Souverains dans l'Empire Romain. Genève: Fondation Hardt, 1973. t.19, p.104.

${ }^{50}$ ROES, A. L'Aigle Psychopompe de l'Époque Impériale. In: Mélanges Charles Picard. Paris: PUF, 1949. t.2, p.881-891.

${ }^{51}$ BICKERMAN, E. Op. cit., p.20-23.

${ }^{52}$ TURCAN, R. Origines et Sens de L'Inhumation à l'Époque Impériale. Revue des Études Anciennes, Paris, v.60, n.3-4, 1958, p.323-347.

${ }^{53}$ RICHARD, J.-C. Énée, Romulus, César et les Funérailles Impériales. Mélanges de l’École Française de Rome, Paris, v.78, 1968, p.67-78.

${ }^{54}$ PRICE, S. R. F. From Noble Funerals to Divine Cult: The Consecration of Roman Emperors. In: CANNADINE, D.; PRICE, S. (ed.). Rituals of Royalty. Cambridge: University Press, 1987. p.58.

${ }^{55}$ Idem, p.68.

${ }^{56}$ CANNADINE, D.; PRICE, S. (ed.). Rituals of Royalty. Cambridge: University Press, 1987. p.1-19.

${ }^{57}$ ROMANO, R. (dir.). Enciclopédia Einaudi. Lisboa: Imprensa Nacional/Casa da Moeda, 1994. p.76389.

${ }^{58}$ DUPONT, F. L’Acteur-Roi ou le Théâtre dans la Rome Antique. Paris: Les Belles Lettres, 1985. p.13-14.

${ }_{59}$ VON STIETENCRON, H. Rituali Funebri e Reincarnazione. Studi e Materiali di Storia delle Religioni, Roma, v.55, n.2, 1989, p.251-265.

${ }^{60}$ BALTY, J. Un Buste Inédit de Septime Sévère. Latomus, Bruxelles, v.20, 1961, p.107-112.

${ }^{61}$ SIMPSON, C.-J. Imp. Caesar Divi Filius. Athenaeum, Pavia, v.86, n.2, 1998, p.435.

${ }^{62}$ NOCK, A. D. Religious Developments from the Close of the Republic to the Reign of Nero. In:

Cambridge Ancient History. Cambridge: University Press, 1966. v.10, p.481-483.

${ }^{63}$ HOPKINS, K. Conquistadores y Esclavos. Barcelona: Península, 1978. p.231.

${ }^{64}$ Idem, p.233-243. 